\title{
Pengaruh Pelatihan terhadap Kinerja Asisten Pembiayaan di PT Bank BNI Syariah
}

\author{
Rizqi Adhyka Kusumawati ${ }^{\boxplus}$ \\ Universitas Islam Indonesia \\ e-mail: rizqi.adhyka@uii.ac.id
}

\begin{abstract}
This study aims to evaluate the training process in the Learning Centre Unit at PT Bank BNI Syariah, (Persero), Tbk. This research is qualitative data collection methods in the form of observation and interviews with parties which is directly related to the activities of the Learning Centre Unit and the training participants. The list of questions had been structured according to Kirkpatrick \& Kirkpatrick's theory as well as theory prevailing performance. Respondents are employees of PT Bank BNI Syariah (Persero), Tbk. especially those who served as a Financing Assistant. The results of observations and interviews show that there is an influence between training and improving the performance of PT Bank BNI Financing Assistant Syariah, (Persero) Tbk. and the behaviour level is the most variable dominantly affect the increase in employee performance after getting training. This is indicated by the percentage increase in the pre-test value and post-test and achievement of employee targets after attending training. Result interviewed 30 participants from 3 generations who attended the training said that $75 \%$ of the training participants were very helpful and happy get training so that helps them in completing work with new knowledge and ways.
\end{abstract}

Keywords: human resources, banking, training, employee performance

\begin{abstract}
Abstrak
Penelitian ini bertujuan untuk mengevaluasi proses pelatihan pada unit Learning Centre di PT Bank BNI Syariah, (Persero), Tbk. Penelitian ini bersifat kualitatif dengan metode pengumpulan data berupa observasi dan wawancara pihak yang terkait langsung aktivitas unit Learning Centre dan peserta pelatihan. Daftar pertanyaan telah disusun sesuai dengan teori Kirkpatrick \& Kirkpatrick serta teori kinerja yang berlaku. Responden merupakan karyawan PT Bank BNI Syariah (Persero), Tbk. khususnya yang bertugas sebagai Asisten Pembiayaan. Hasil dari observasi dan wawancara menunjukkan bahwa terdapat pengaruh antara pelatihan dan peningkatan kinerja Asisten Pembiayaan PT Bank BNI Syariah (Persero), Tbk. dan level behaviour merupakan variabel yang paling dominan mempengaruhi peningkatan kinerja karyawan setelah mendapatkan pelatihan. Hal tersebut diindikasikan dari prosentase peningkatan nilai pre- test dan post-test serta pencapaian target karyawan setelah mengikuti pelatihan. Hasil wawancara pada 30 orang peserta dari 3 angkatan yang mengikuti pelatihan menyampaikan bahwa $75 \%$ peserta pelatihan sangat tebantu dan senang mendapatkan pelatihan sehingga membantu mereka dalam menyelesaikan pekerjaan dengan pengetahuan dan cara-cara baru.
\end{abstract}

Kata kunci: sumber daya manusia, perbankan, pelatihan, kinerja karyawan 


\section{PENDAHULUAN}

Perubahan fungsi sumber daya manusia (SDM) saat ini telah mengalami proses yang sangat cepat. Pergeseran peran dari pelaksana aktivitas perusahaan telah bergeser menjadi pengambil keputusan dalam perusahaan. Hal tersebut disebabkan adanya kemajuan teknologi yang semakin canggih sehingga aktivitas-aktivitas mendasar mulai dilakukan oleh mesin atau aplikasi. Dalam bidang perbankan di Indonesia, teknologi bahkan telah menjadi tren yang berdampak pada meningkatnya laba perbankan dikarenakan adanya ketertarikan para nasabah terhadap kemudahan penggunaan layanan perbankan.

Salah satu ilustrasi nyata adalah mulai digunakannya aplikasi pembayaran operasional rumah tangga sehari-hari (seperti pembayaran tagihan listrik, tagihan air, dan tagihan tiket kereta-pesawat-dan lain sebagainya) yang biasanya dilakukan di luar rumah (beberapa melalui mekanisme setor tunai di payment point), saat ini dapat dilakukan di dalam rumah. Tidak hanya berbentuk aplikasi, bank pun melakukan 'perpanjangan tangan' dengan memunculkan produk agensi pembayaran yang dapat mengakomodir kebutuhan tarik tunai uang dan kirim uang melalui produk jasa yang biasanya disebut dengan 'agen' seperti di BNI bernama Agen 46, di Bank Bukopin bernama Loket PPOB (Payment Point Online Bank), di BRI bernama Teras BRI, dan lain sebagainya.

Beragamnya produk jasa sejenis membawa dampak pada pengurangan karyawan atau pegawai bank di Indonesia. Sebaliknya, industri perbankan mulai berminat mengalihkan peran SDM tersebut ke sistem informasi, aplikasi pada gadget, dan teknologi perbankan lainnya sehingga karyawan perbankan yang tersisa adalah karyawan memiliki prestasi, kemampuan, keahlian, bakat dan kinerja terbaik.

Dalam rangka merawat, memperbarui, dan menjaga kemampuan para karyawan yang berprestasi, industri perbankan melakukan aktivitas yang mendukung para karyawannya untuk berkinerja lebih baik dan salah satu upaya untuk meningkatkan kapabilitas karyawan tersebut, yaitu pelatihan karyawan.

Para karyawan dibekali dengan ilmu dan keterampilan kerja dengan tujuan agar dapat memberikan kontribusi yang optimal bagi perbankan. Selain itu, seiring dengan perkembangan teknologi yang semakin canggih, dalam rangka mengelola talent (talent management) yang dimiliki oleh para karyawan, pelatihan juga diberikan agar motivasi kerja meningkat dan tercipta loyalitas karyawan terhadap perusahaan.

Pengelolaan talent melalui pelatihan merupakan cara atau strategi perusahaan saat ini yang bertujuan untuk meminimalisir biaya SDM dan meningkatkan pendapatan atau laba perusahaan. Hal tersebut dikarenakan mayoritas perusahaan di Indonesia saat ini lebih memilih untuk menggunakan teknologi dan mesin-mesin dibandingkan dengan menggunakan SDM yang dinilai tidak potensial pengelolaannya. Namun, tidak dapat dipungkiri bahwa era milenial saat ini juga masih membutuhkan campur tangan manusia dalam hal pengoperasian serta pengambilan keputusan karena mesin tidak mampu berpikir dengan hati. Begitu juga yang terjadi dengan PT BNI Syariah di mana Asisten Pembiayaan diharapkan tetap menjadi garda depan dalam bisnis perbankan mendapatkan laba dan mencapai target perbankan yang telah ditetapkan di awal tahun.

Kerasnya bisnis perbankan khususnya dalam bidang pembiayaan, membuat para petugasnya di lapangan kehilangan semangat dan motivasi kerja. Umumnya, Asisten Pembiayaan yang bertugas menjual produk pembiayaan seringkali berpindah-pindah tempat kerja sehingga tingkat turnover karyawan, khususnya pada posisi Asisten Pembiayaan, meningkat. Tidak hanya itu, loyalitas juga menjadi isu berikutnya yang muncul akibat hilangnya motivasi karyawan yang potensial. 
Salah satu upaya dalam memberikan solusi terhadap permasalahan tersebut adalah melakukan penelitian ini. Penelitian yang membahas tentang pentingnya proses evaluasi pelatihan dan dampaknya pada semua variable yang mungkin timbul dari selesainya proses pelatihan tersebut. Perusahaan seringkali lupa, bahwa apa yang terjadi dua hingga lima tahun ke depan merupakan hasil dari sukses tidaknya proses pelatihan itu dilakukan. Evaluasi pasca pelatihan seringkali tidak disertai dengan monitoring berkala pada kinerja karyawan. Perusahaan merasa sudah cukup baik apabila setelah menyelesaikan pelatihan, karyawan mampu meningkatkan kinerja dengan capaian hasil yang optimal sehingga penulis masih merasa ada celah penelitian yang dapat dilakukan dengan mengumpulkan dan mengolah beberapa data yang tersedia di perusahaan.

Pelatihan adalah suatu aktivitas peningkatan pengetahuan dan keterampilan seorang karyawan dalam rangka menerapkan aktivitas pekerjaan yang telah ditentukan (Flippo, 2018). Menurut Werther \& Davis (1996), pelatihan merupakan aktivitas pengembangan dalam membantu karyawan melakukan pekerjaan serta memberikan keuntungan dalam jenjang karir dan meningkatkan atau menumbuhkan rasa tanggung jawab yang lebih dalam terhadap suatu pekerjaan di masa depan.

Bagi karyawan, pelatihan seringkali dianggap sebagai penghargaan atas kontribusi yang telah diberikan maupun kinerja yang dihasilkan oleh karyawan sehingga karyawan makin termotivasi untuk memberikan segala hal lebih baik lagi kepada perusahaan, khususnya kinerja karyawan.

Dalam melaksanakan pelatihan, terdapat beberapa komponen pelatihan yang merupakan unsur terciptanya suatu pelatihan yaitu peserta pelatihan, pelatih, jangka waktu pelatihan, bahan atau materi pelatihan, dan bentuk pelatihan (Hamalik, 2000). Penetapan calon peserta pelatihan erat kaitannya dengan keberhasilan proses pelatihan, yang pada akhirnya menentukan efektivitas pekerjaan. Oleh karenanya, perlu dilakukan proses seleksi yang teliti untuk memperoleh peserta yang baik dan sesuai kriteria.

Para pelatih atau instruktur memiliki peran yang sangat penting terhadap kelancaran dan kesuksesan program pelatihan, sehingga perlu dilakukan pemilihan pelatih yang ahli dan memiliki kualifikasi profesional. Lamanya masa pelatihan didasarkan dari pertimbangan jumlah dan mutu kemampuan, kemampuan belajar para peserta, serta media pengajaran. Bahan pelatihan disiapkan dengan layak secara tertulis agar mudah dipelajari oleh para peserta. Komponen terakhir adalah bentuk pelatihan yang digunakan untuk mengembangkan kemampuan ketenagaan.

Selain unsur-unsur tersebut di atas, pelatihan juga memiliki tujuan dalam pelaksanaannya agar pelatihan yang diselenggarakan tepat guna. Menurut Simamora (1998), terdapat 7 tujuan utama pelatihan. Tujuh tujuan tersebut adalah (1) perbaikan kinerja, (2) pemutakhiran keahlian para karyawan sejalan dengan kemajuan teknologi, (3) meminimalisir waktu belajar bagi karyawan baru agar menjadi kompeten dalam pekerjaan, (4) membantu memecahkan masalah operasional, (5) persiapan promosi karyawan, (6) penanaman orientasi karyawan terhadap organisasi, dan (7) pemenuhan kebutuhan pertumbuhan pribadi.

Pelatihan dapat dilakukan dengan berbagai teknik dan cara sesuai dengan kebutuhannya. Teknik pelatihan menurut Simamora (1998) terbagi menjadi dua klasifikasi, yaitu on-the-job training dan off-the-job training.

Teknik on-the-job training digunakan untuk pelatihan yang bersifat singkat jangka waktunya dan langsung dapat diaplikasikan di tempat kerja. Teknik ini meliputi magang, internship, dan rotasi pekerjaan.

Teknik off-the-job training digunakan untuk pelatihan yang bersifat luas karena 
dilakukan di tempat terpisah dari tempat kerja (di luar kantor). Pada teknik ini, para peserta pelatihan diberikan pengetahuan dan keahlian yang dibutuhkan untuk melaksanakan pekerjaan pada waktu terpisah dari waktu kerja regular mereka. Teknik ini meliputi kuliah, studi kasus, simulasi computer, pelatihan beranda, role play (bermain peran), peniruan perilaku, pelatihan alam terbuka, dan pelatihan sensitivitas.
Setelah dilakukan pelatihan, maka seluruh proses dan tahapan aktivitas akan dievaluasi untuk mendapatkan hasil pelatihan dan mengetahui apakah pelatihan yang dilakukan telah sesuai tujuannya dan tepat guna untuk perusahaan. Beberapa level evaluasi pelatihan menurut Kirkpatrick \& Kirkpatrick (2006) dirangkum pada Gambar 1.

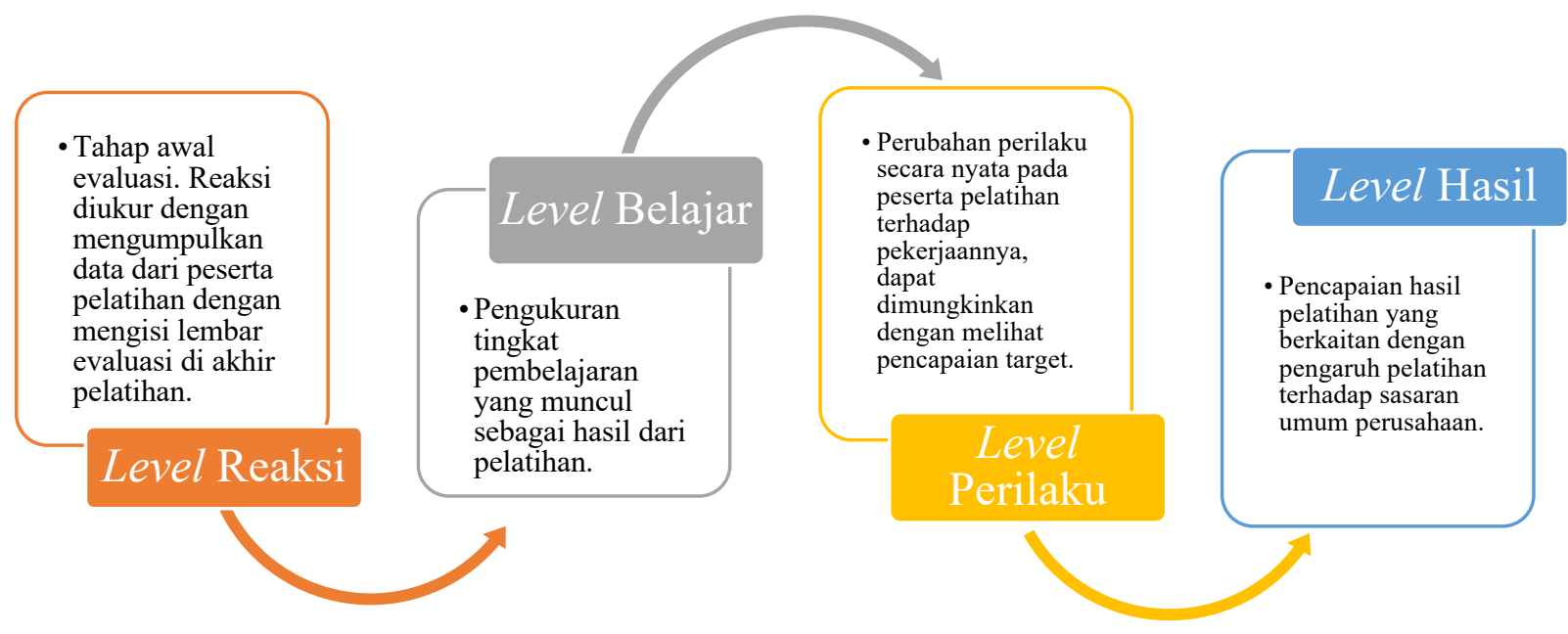

Gambar 1. Empat Level Evaluasi Pelatihan Kirkpatrick

Berdasarkan tahapan-tahapan tersebut, pelaksanaan pelatihan dapat termonitor dengan baik dan kesesuaiannya dengan tujuan pelatihan dapat terukur.

\section{Definisi Kinerja Karyawan}

Sebuah organisasi dikatakan dapat membangun keunggulan bersaing ketika perusahaan tersebut dapat memberdayakan sumber daya manusianya secara optimal dalam rangka pencapaian tujuan perusahaan. Perusahaan seperti ini, hanya memiliki pilihan untuk menerapkan sistem manajemen kinerja dimana kualitas individu atau hasil yang dicapai, secara fundamental ditentukan oleh keahlian dan kemampuan individu yang bersangkutan (Alwi, 2008). Kinerja dapat diartikan sebagai hasil dari pekerjaan yang terkait dengan tujuan organisasi, efesiensi, dan keefektifan kinerja lainnya (Gibson dkk.,
1997). Menurut Simamora (2004) maksud penetapan tujuan kinerja adalah menyusun sasaran yang berguna tidak hanya bagi evaluasi kinerja pada akhir periode telaah, tetapi juga untuk mengelola proses kerja selama periode tersebut. Ada tidaknya alasan mengapa penentuan sasaran mempengaruhi kinerja antara lain penentuan sasaran mempunyai dampak mengarahkan yaitu memfokuskan aktivitas ke arah tertentu dari pada lainnya. Sasaran yang telah diterima maka orang cenderung mengerahkan upaya secara proposional terhadap kesulitan, serta sasaran yang sukar akan membuahkan kekuatan dibandingkan sasaran yang ringan.

Penilaian kinerja juga memungkinkan karyawan menyusun suatu rencana untuk memperbaiki setiap hal yang dapat diketahui. Dengan demikian maka kinerja adalah suatu hasil kesuksesan yang dicapai 
oleh karyawan dalam bidang pekerjaannya menurut kriterianya yang berlaku untuk suatu pekerjaan tertentu dan dievaluasi oleh orang-orang tertentu. Karena pada dasarnya kinerja karyawan bersifat individu dimana tiap-tiap karyawan memiliki kemampuan dan keahlian yang berbeda.

Untuk mengukur kinerja, terlebih dahulu harus ditetapkan kriterianya. Menurut Bernardin (2010), terdapat enam kriteria untuk menilai kinerja karyawan, yaitu quality, quantity, timeliness, cost effectiveness, need for supervision, dan interpersonal impact. Meskipun semua kriteria tersebut mungkin tidak relevan dengan setiap aktivitas pekerjaan atau fungsi pekerjaan, namun sebuah subset dari kriteria tersebut dapat terjadi sehingga penting bagi perusahaan untuk mengenali hubungan antar kriteria. Karena penilaian kinerja yang efektif berfokus pada catatan hasil dan sebagian hasil secara langsung berhubungan dengan tujuan dan misi perusahaan.

\section{Penelitian yang Relevan}

Penelitian tentang pengaruh pelatihan terhadap kinerja karyawan telah banyak dilakukan di Indonesia. Beberapa penelitian dengan topik yang sama dilakukan di PT Gatra Mapan Malang tahun 2005, Dinas Pendidikan Kabupaten Sorolangun tahun 2014, PT BPRS Bumi Rinjani Kepanjen tahun 2015, dan PT Posindo (Persero) Regional V Bandung tahun 2016. Masingmasing penelitian memiliki variabel bebas yang berbeda dan variabel terikat yang sama yaitu Kinerja Karyawan.

Penelitian yang dilakukan oleh Graha (2005) menemukan bahwa dari lima variabel pelatihan (tenaga pelatihan, materi pelatihan, metode pelatihan, fasilitas pelatihan, dan lama pelatihan) diperoleh skor rata-rata jawaban responden lebih dari 3,00. Hal ini berarti bahwa hasil analisis deskriptif dari variabel-variabel tersebut yang mempengaruhi kemampuan kerja sudah baik dan sesuai. Selain itu, berdasarkan hasil analisis regresi linier berganda dapat diketahui secara bersama- sama yang terdiri dari tenaga pelatihan, materi pelatihan, metode pelatihan, fasilitas pelatihan, dan lama pelatihan memiliki pengaruh yang signifikan terhadap kemampuan karyawan. Nilai koefisien korelasi berganda yang diperoleh adalah sebesar 0,628. Hal ini dapat diartikan bahwa terdapat hubungan yang kuat antara variabel bebas (tenaga pelatihan, materi pelatihan, metode pelatihan, fasilitas pelatihan, dan lama pelatihan) terhadap variabel terikat (kemampuan karyawan). Nilai adjusted $\mathrm{R}^{2}$ yang diperoleh adalah sebesar 0,349. Variasi perubahan nilai kemampuan karyawan dapat dijelaskan oleh seluruh variabel bebas secara bersamasama sebesar $34,9 \%$ dan sisanya $65,1 \%$ dipengaruhi oleh variabel lain yang tidak dimasukkan dalam model.

Kemudian Dahmiri \& Sakta (2014) mengemukakan bahwa pelatihan memberikan kontribusi terhadap kinerja pegawai Dinas Pendidikan Kabupaten Sorolangun dengan angka koefisien determinasi $\left(\mathrm{R}^{2}\right)$ sebesar 0,253. Hal ini berarti $25,3 \%$ perubahan pada variabel kinerja pegawai dapat diterangkan oleh pengaruh pelatihan.

Selanjutnya, penelitian tentang pelatihan terhadap kinerja karyawan tetap dilakukan dan dilanjutkan oleh beberapa peneliti, dua diantaranya yaitu oleh Endayani (2015) dan Harahap \& Silvianita (2016). Penelitian Endayani (2015) menyimpulkan bahwa berdasarkan hasil analisis regresi linier berganda menunjukkan bahwa kinerja karyawan dipengaruhi oleh metode dan materi pelatihan hanya sebesar $32,5 \%$ sedangkan $67,5 \%$ dipengaruhi oleh faktor atau variabel lain yang tidak dibahas pada model (residual error). Hasil analisis setelah melibatkan variabel moderating, yaitu kemampuan kerja, menunjukkan bahwa kinerja karyawan dipengaruhi oleh metode dan materi pelatihan menjadi naik sebesar $49,2 \%$.

Harahap \& Silvianita (2016) mengungkap bahwa variabel Tujuan, Sasaran, Pelatih, Materi, Metode, dan 
Peserta memiliki pengaruh secara simultan atau bersama-bersama terhadap Kinerja Karyawan PT Pos Indonesia (Persero) Regional V Bandung.

Sampai saat ini, penelitian terkait pengaruh pelatihan terhadap kinerja merupakan tema yang menarik dan masih hangat dibahas di lingkungan bisnis. Persamaan dari penelitian terdahulu dengan penelitian ini adalah sama-sama meneliti tentang pengaruh pelatihan terhadap kinerja karyawan, namun dengan menggunakan dasar teori yang berbeda. Beberapa perbedaan dari penelitian ini dengan penelitian terdahulu yaitu penelitian terdahulu tidak dilakukan di Lembaga
Keuangan Bank, sedangkan penelitian ini dilakukan di PT BNI Syariah. Variabel terikat yang menjadi hipotesis penelitian diambil dari teori Kirkpatrick \& Kirkpatrick yang menggunakan evaluasi pelatihan untuk mengukur ada tidaknya pengaruh pelatihan terhadap kinerja karyawan.

Tujuan dari penelitian ini adalah untuk (1) mengetahui pengaruh pelatihan terhadap kinerja Asisten Pembiayaan di PT Bank BNI Syariah dan (2) mengetahui variabel dari pelatihan yang paling dominan memiliki pengaruh dengan kinerja Asisten Pembiayaan di PT Bank BNI Syariah. Gambar 2 menampilkan kerangka pemikiran dari penelitian ini.

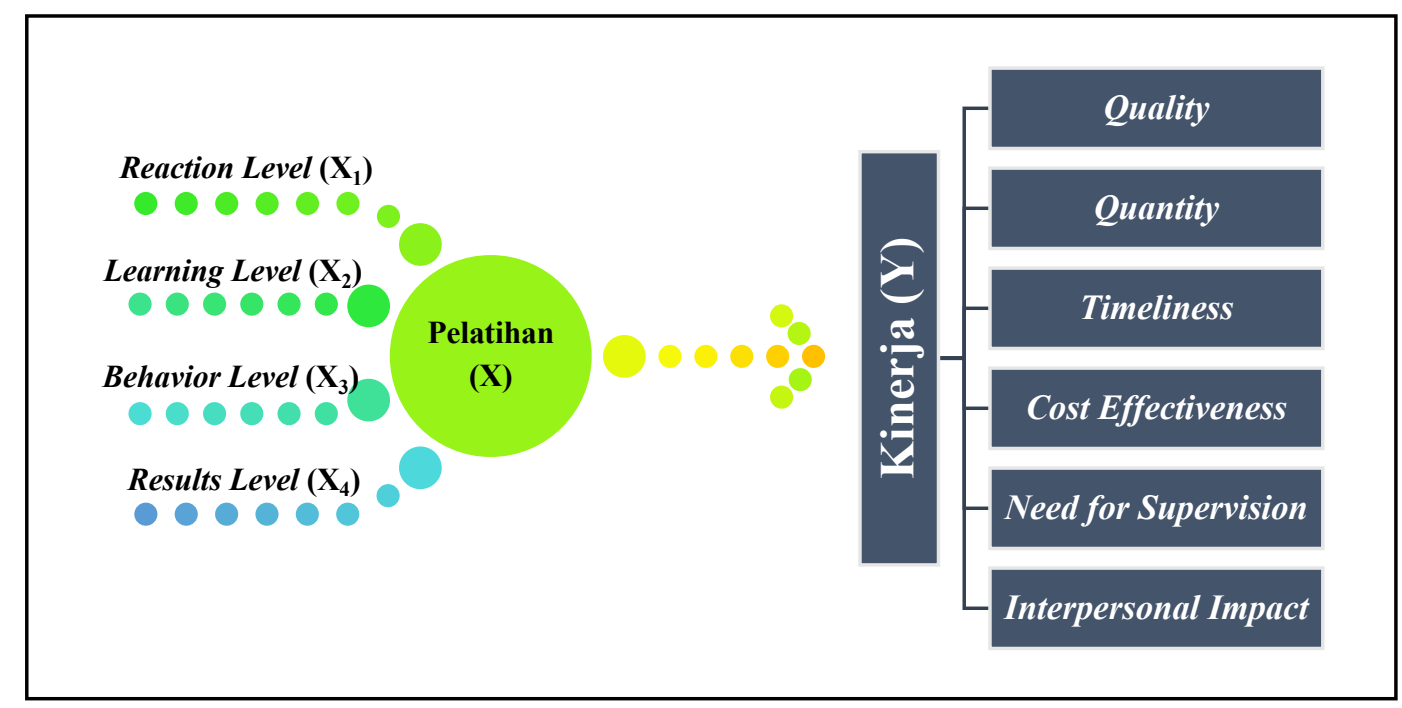

Gambar 2. Kerangka Pemikiran

\section{METODE PENELITIAN}

Penelitian yang dilakukan ini adalah jenis penelitian kualitatif dengan pendekatan studi kasus yang mengumpulkan informasi melalui metode wawancara dan observasi lapangan.

Observasi ditujukan pada bagaimana proses pelatihan dilaksanakan dan mengevaluasi proses pelaksanaan pelatihan dengan menggunakan Teori Kirkpatrick \& Kickpatrick melalui empat level evaluasi pelatihan, sedangkan wawancara dilakukan pada karyawan PT Bank BNI Syariah yang berprofesi sebagai Asisten Pembiayaan di seluruh Kantor Cabang Bank BNI di Indonesia yang telah mengikuti pelatihan di Divisi Pelatihan PT BNI Syariah.
Dalam penelitian ini terdapat dua jenis variabel, yaitu variabel bebas (independent variable) dan variabel terikat (dependent variable). Variabel terikat dalam penelitian ini adalah variabel Kinerja Karyawan. Variabel tersebut adalah variabel yang dipengaruhi atau yang menjadi akibat adanya variabel bebas (Sugiyono, 2006). Dalam penelitian ini variabel dependen adalah kinerja Asisten Pembiayaan di PT Bank BNI Syariah.

Adapun variabel bebas dalam penelitian ini adalah variabel Pelatihan. Variabel tersebut adalah variabel yang mempengaruhi atau menjadi sebab timbulnya variabel dependen (Sugiyono, 2006). Dalam penelitian ini variabel 
independen berupa Pelatihan yang telah dilaksanakan PT Bank BNI Syariah.

Pelatihan merupakan salah satu proses atau aktivitas yang dilakukan oleh sebuah perusahaan dalam rangka pengembangan karyawan dan peningkatan keahlian serta kemampuan yang dimiliki oleh karyawan-karyawan potensial. Dalam menyelenggarakan pelatihan, suatu perusahaan terlebih dulu harus melakukan training need analysis dengan tahap awal mengidentifikasi kebutuhan bisnis perusahaan. Kemudian mengidentifikasi dan menganalisa isu-isu yang terkait dengan perkembangan pasar dan bisnis. Setelah itu, menentukan indikator-indikator pencapaian target serta mendesain dan membangung program pembelajaran dan alat-alat evaluasi program pelatihan (Kirkpatrick \& Kirkpatrcik, 2009).

Dalam melakukan penilaian pada pelatihan dan dampak serta pengaruhnya terhadap kinerja, Kirkpatrick \& Kirkpatrick (2009) mengemukakan bahwa terdapat empat level evaluasi pelatihan yang dimulai dari tahapan terakhir yaitu Level Hasil (Results Level). Level 1, yaitu Reaction, mengindikasikan sejauh mana peserta memberikan reaksi suka terhadap proses belajar. Level 2, yaitu Learning, mengukur sejauh mana peserta dapat memahami dan memperoleh maksud dari pengetahuan, keterampilan, dan sikap berdasarkan partisipasi mereka dalam acara pembelajaran. Level 3, yaitu Behavior, mengukur sejauh mana peserta dapat mengaplikasikan ilmu yang telah diberikan saat pelatihan dalam pekerjaan setelah mereka kembali bekerja. Level 4, yaitu Results, menilai pencapaian target yang dihasilkan dari dampak mengikuti pelatihan.

Tingkatan atau level tersebut merupakan tahapan proses evaluasi pelatihan yang sering dilakukan perusahaan dalam rangka mendapatkan masukan perbaikan dan memperbaiki programprogram pelatihan yang dibuat sesuai dengan kebutuhan perusahaan sehingga dapat menciptakan pelatihan bernilai tambah baik bagi karyawan maupun perusahaan.

Kinerja adalah hasil dari pekerjaan yang terkait dengan tujuan organisasi, efisiensi, dan keefektifan kinerja lainnya (Gibson dkk, 1997). Menurut Bernardin (2010), terdapat enam kriteria untuk menilai kinerja karyawan, yaitu quality, quantity, timeliness, cost effectiveness, need for supervision, dan interpersonal impact. Quality merupakan tingkatan dimana proses atau penyesuaian pada cara yang ideal dalam melakukan aktivitas atau memenuhi aktivitas yang sesuai harapan.

Quantity adalah jumlah yang dihasilkan dan diwujudkan melalui nilai mata uang, jumlah unit, atau jumlah dari siklus aktivitas yang telah diselesaikan. Timeliness merupakan tingkatan dimana aktivitas telah diselesaikan dengan waktu yang lebih cepat dari yang ditentukan dan memaksimalkan waktu yang ada untuk aktivitas lain. Cost effectiveness merupakan tingkatan dimana penggunaan sumber daya perusahaan yang berupa manusia, keuangan, dan teknologi dimaksimalkan untuk mendapatkan hasil yang tertinggi atau pengurangan kerugian dari tiap unit.

Need for supervision merupakan tingkatan di mana seorang karyawan dapat melakukan pekerjaannya tanpa perlu meminta pertolongan atau bimbingan dari atasannya. Interpersonal impact merupakan tingkatan dimana seorang karyawan merasa percaya diri, memiliki keinginan yang baik, dan bekerja sama diantara rekan kerja.

\section{Teknik Pengambilan Sampel}

Pada penelitian kualitatif tidak terdapat populasi dan sampel, melainkan terdapat empat level pelatihan dan dampak terhadap kinerja Asisten Pembiayaan yang akan dikonfirmasi dan diminta penjelasannya, yaitu reaction, learning, behavior, dan results. Penentuan sumber data pada tempat, aktivitas, dan orang yang akan diwawancarai dilakukan dengan memilih sesuai pertimbangan dan tujuan penelitian.

$$
\text { Terdapat beberapa informan }
$$

penelitian pada Unit Learning Center- 
Divisi Sumber Daya Insani PT Bank BNI Syariah, yaitu manajer unit, asisten manajer, asisten unit, dan peserta pelatihan. Penelitian dilakukan dengan mengumpulkan data dari populasi dan sampel. Jumlah sampel yang akan diambil dari tiap bagian adalah sebanyak 5-10 sampel, sehingga total sampel dari keseluruhan bagian adalah sebanyak 30 karyawan dengan waktu penelitian direncanakan selama enam bulan mulai bulan Juli 2019 sampai dengan Desember 2019 pada tiga batch pelatihan.

Populasi adalah wilayah generalisasi yang terdiri atas obyek/subyek yang mempunyai kuantitas dan karakteristik tertentu yang ditetapkan oleh peneliti untuk dipelajari dan kemudian ditarik kesimpulannya (Sugiyono, 2006). Populasi dalam penelitian ini adalah seluruh karyawan yang termasuk dalam jenjang jabatan Asisten, khususnya yang bertugas sebagai Asisten Pembiayaan di PT BNI Syariah.

Sampel adalah sebagian dari jumlah dan karakteristik yang dimiliki oleh populasi tersebut (Sugiyono, 2006). Pada penelitian ini teknik sampling yang digunakan adalah metode convenience sampling, yaitu metode memilih sampel dari elemen populasi yang mudah diperoleh datanya (Indriantoro \& Supomo, 1999). Sampel penelitian ini adalah seluruh karyawan yang bekerja di PT BNI Syariah yang bertugas sebagai Asisten Pembiayaan di PT BNI Syariah dan termasuk dalam daftar pelatihan yang telah ditetapkan oleh PT BNI Syariah. Para peserta pelatihan tersebut akan mengisi kuesioner dan menjadi sumber data terkait kinerja Asisten Pembiayaan di PT BNI Syariah.

\section{Teknik Pengumpulan Data}

Dalam rangka pengumpulan data, teknik yang sesuai adalah dengan wawancara dan observasi langsung. Pengumpulan data lapangan dimulai dengan melaksanakan observasi penelitian tentang faktor yang diteliti. Wawancara dilakukan secara private sehingga informasi yang disampaikan oleh informan diberikan dengan detail dan mendalam sesuai dengan fokus tema penelitian.

\section{Teknik Analisis Data}

Data yang telah diperoleh dalam penelitian ini dianalisis dengan metode deskriptif analisis yang bertujuan mampu memberikan gambaran secara sistematis, rinci, dan menyeluruh tentang proses pelaksanaan pelatihan pada Unit Learning Center di PT Bank BNI Syariah (Persero) Tbk serta proses analisis dalam rangka menjawab permasalahan yang terdapat dalam rumusan masalah.

Seluruh data, baik yang diperoleh melalui observasi maupun wawancara, dikompilasi menjadi satu data komprehensif untuk kemudian diolah dan dianalisis secara kualitatif dengan memperhatikan fakta-fakta di lapangan.

\section{HASIL DAN PEMBAHASAN Proses Evaluasi Pelatihan di PT Bank BNI Syariah (Persero) Tbk}

Pelatihan di PT Bank BNI Syariah diselenggarakan oleh Unit Learning Center, Divisi Sumber Daya Insani di Jakarta. Setiap pelaksanaan pelatihan dalam setahun dapat mengikutsertakan lebih kurang 500 peserta. Khusus untuk karyawan yang bertugas sebagai asisten pembiayaan, peserta pelatihan per tahun dapat mencapai 100-150 orang dari seluruh cabang di Indonesia. Satu angkatan pelatihan dapat terdiri dari 30-50 peserta. Hal tersebut disesuaikan dengan kebutuhan perusahaan dan tujuan dari pelatihan.

Pelaksanaan pelatihan di PT Bank BNI Syariah dilakukan secara inhouse maupun public. Tabel 1 menampilkan perbedaan antara inhouse training dan public training.

Unit Learning Center dalam memilih jenis penyelenggaraan pelatihan menyesuaikan dengan jenis pelatihan yang akan dilakukan sehingga hasil dan dampak dari pelatihan dapat sesuai dengan tujuan perusahaan. Tabel 2 merangkum jenis 
pelatihan berdasarkan jenjang jabatan di PT

Bank BNI Syariah tahun 2018.

Tabel 1. Perbedaan Inhouse Training dan Public Training

Inhouse Training

1. Isi materi pelatihan lebih spesifik karena disesuaikan dengan kebutuhan perusahaan

klien.

2. Lebih fokus karena seluruh peserta berasal dari satu perusahaan.

3. Umumnya pemateri (trainer) melakukan survei terlebih dahulu atau melakukan Training Need Analysis agar pelatihan yang diberikan sesuai kebutuhan klien.

\begin{tabular}{l} 
4. Trainer dapat dengan mudah \\
mengumpulkan data awal dari perusahaan \\
klien terkait kebutuhan, latar belakang trainee, \\
dan harapan dari perusahaan. \\
\hline 5. Perusahaan klien dapat memberikan \\
masukan atau pesan yang ingin diselipkan \\
diantara isi materi training.
\end{tabular}

6. Dalam jangka panjang dari segi biaya, hasil, waktu dan dampak, inhouse training lebih efektif jika dibandingkan dengan public training.

7. Ada jumlah minimal peserta dan atau minimal biaya yang harus dibayarkan agar inhouse training dapat dilaksanakan di perusahaan klien.

8. Perlu persiapan lebih matang karena perusahaan klien harus menyediakan tempat penyelenggaraan pelatihan, konsumsi selama pelatihan berlangsung, dan peralatan pendukung lainnya seperti LCD Proyektor dan sound system, serta wifi.

Berdasarkan Tabel 2, dapat diketahui bahwa terdapat 25 jenis pelatihan yang diikuti oleh pegawai dengan jenjang jabatan Asisten. Khusus untuk pegawai berjenjang jabatan Asisten dan bertugas di Unit Pembiayaan, terdapat 11 pelatihan yang sesuai, yaitu pelatihan Assistant Development Program, Recovery \& Remedial, Product Knowledge, Collection Manager, Pembiayaan Mikro, Selling Skill,

\section{Public Training}

1. Isi materi sudah baku dan sangat umum, tidak sampai membahas semua masalah dan tidak memenuhi kebutuhan yang ada di masing-masing perusahaan klien.

2. Hanya fokus pada isi materi training tetapi tidak terlalu fokus pada kebutuhan, permasalahan, dan kasus pada masing-masing perusahaan peserta.

3. Umumnya trainer tidak dapat melakukan survei dan wawancara dalam proses Training Need Analysis.

4. Trainer hanya dapat menebak masalah, kebutuhan, dan latar belakang trainee serta harapan dari perusahaan peserta dari daftar peserta pelatihan.

5. Perusahaan klien tidak dapat memberikan masukan atau pesan yang ingin diselipkan antara isi materi training.

6. Dalam jangka panjang dari segi biaya, hasil, waktu dan dampak, public training tidak lebih efektif jika dibandingkan dengan inhouse training.

7. Keuntungan public training adalah perusahaan dapat mengirimkan minimal hanya satu atau dua peserta.

8. Tidak perlu mempersiapkan dengan matang karena seluruh aktivitas persiapan pelatihan telah dilakukan oleh penyelenggara public training.
Communication Skill, Negotiation Skill, Pengembangan Kartu Pembiayaan, Legal \& Compliance, dan Administrasi Pembiayaan.

Mayoritas dari 11 pelatihan tersebut dilakukan secara inhouse training karena jumlah pesertanya yang lebih dari 10 orang per angkatan dan adanya permintaan khusus terkait materi bagi para Asisten Pembiayaan. 
Tabel 2. Klasifikasi Jenis Pelatihan Berdasarkan Jenjang Jabatan di PT Bank BNI Syariah Tahun 2018

\begin{tabular}{|c|c|c|}
\hline Jenis Pelatihan & $\begin{array}{l}\text { Nama Pelatihan } \\
\end{array}$ & Jenjang Jabatan \\
\hline \multirow[t]{5}{*}{ Inhouse Training } & $\begin{array}{l}\text { 1. Assistant Development Program } \\
\text { 2. Bina Hasanah }\end{array}$ & Clerk \\
\hline & $\begin{array}{l}\text { 3. Program Talent Management } \\
\text { 4. Recovery \& Remedial } \\
\text { 5. Treasuri \& International } \\
\text { 6. Manajemen SDM }\end{array}$ & Clerk-Executive Manager \\
\hline & $\begin{array}{l}\text { 7. Product Knowledge } \\
\text { 8. PDPS } \\
\text { 9. Collection Manager } \\
\text { 10. APU \& PPT }\end{array}$ & Clerk-Junior Manager \\
\hline & $\begin{array}{l}\text { 11. Standar Layanan } \\
\text { 12. Pembiayaan Mikro } \\
\text { 13. Selling Skill } \\
\text { 14. Communication Skill } \\
\text { 15. Brevet Konsumer } \\
\text { 16. Negotiation Skill } \\
\text { 17. Microsoft Excel Mikro, Excell Macro, SQL } \\
\text { 18. Pengembangan Kartu Pembiayaan } \\
\text { 19. Pengadaan dan Pemeliharaan Aset }\end{array}$ & Clerk-Manager \\
\hline & 20. Administrasi Pembiayaan & Clerk-Senior Manager \\
\hline \multirow[t]{3}{*}{ Public Training } & $\begin{array}{l}\text { 1. Brevet Pajak } \mathrm{A} / \mathrm{B} / \mathrm{ABC} \\
\text { 2. Kesekretariatan }\end{array}$ & Clerk \\
\hline & $\begin{array}{l}\text { 3. Legal \& Compliance } \\
\text { 4. Project Management }\end{array}$ & Clerk-Manager \\
\hline & 5. Sertifikasi Akuntansi & Clerk-Senior Manager \\
\hline
\end{tabular}

Pada penelitian ini, aktivitas yang mendukung terlaksananya pelatihan penelitian difokuskan pada pelatihan dengan baik telah dilakukan oleh Unit Administrasi Pembiayaan bagi Asisten Learning Center sebagai penyelenggara Pembiyaan. Hasil observasi pada Tabel 3 menunjukkan bahwa beberapa hal penting (inhouse training).

Tabel 3. Checklist Observasi Pelatihan Administrasi Pembiayaan 2018

\begin{tabular}{llc}
\hline Hal yang diamati & \multicolumn{1}{c}{ Hasil Pengamatan } & Keterangan \\
\hline Peserta Pelatihan & $\begin{array}{l}\text { Peserta pelatihan telah diseleksi } \\
\text { terlebih dahulu melalui proses } \\
\text { penilaian kinerja (PKPP) dari } \\
\text { atasan dan usulan cabang. }\end{array}$ & Terpenuhi \\
\hline Instruktur Pelatihan & $\begin{array}{l}\text { Trainer merupakan orang yang } \\
\text { memiliki reputasi sangat baik dan } \\
\text { (Trainer) }\end{array}$ & Terpenuhi \\
& $\begin{array}{l}\text { dikenal profesional di bidangnya. } \\
\text { kebutuhan pada hasil Training }\end{array}$ & \\
\hline Jangka Waktu & $\begin{array}{l}\text { Need Analysis dan status pegawai } \\
\text { (kontrak, tetap, baru, atau yang }\end{array}$ & \\
& $\begin{array}{l}\text { telah berpengalaman selama } \\
\text { beberapa tahun dengan penilaian }\end{array}$ & \\
& kinerja). & \\
\hline Bahan/materi & $\begin{array}{l}\text { Sesuai dengan spesifikasi } \\
\text { pekerjaan masing-masing jabatan } \\
\text { Pelatihan }\end{array}$ & Terpenuhi \\
& Inhoune Training & \\
\hline Bentuk Pelatihan & & Terpenuhi \\
\hline
\end{tabular}


Tabel 4. Hasil Wawancara pada Pelatihan Administrasi Pembiayaan 2018

Pernyataan Evaluasi Pelatihan Respon/jawaban responden

Materi pelatihan yang diberikan $\quad 75 \%$ dari 30 peserta atau sebanyak 23 orang berhubungan dengan pekerjaan merespon positif bahwa materi pelatihan sesuai sebagai Asisten Pembiayaan. dengan pekerjaan Asisten Pembiayaan dan sisanya sebanyak 7 orang merespon bahwa materi pelatihan masih ada kekurangan terkait kesesuaian dengan pekerjaan sebagai Asisten Pembiayaan.

Materi dibawakan dengan menarik. Seluruh responden merespon positif bahwa materi dibawakan dengan menarik sehingga terserap dengan baik dan dapat diaplikasikan dalam bidang pekerjaan.

Pemateri berkomunikasi secara Seluruh responden merespon positif bahwa efektif. $\quad$ pemateri berkomunikasi dua arah dan selalu memastikan kepahaman peserta pelatihan sebelum lanjut ke materi berikutnya. Sesi tanya jawab tidak dilakukan secara khusus, namun langsung dilakukan dengan bentuk diskusi di ruang pelatihan.

Pemateri mempersiapkan diri $\quad$ Seluruh responden merespon positif bahwa dengan baik. pemateri mempersiapkan diri dengan baik. Hal tersebut ditunjukkan dari keaktifan para peserta berdiskusi dengan pemateri di dalam ruang kelas maupun di luar ruang kelas ketika break.

Pelatihan disertai dengan audioSeluruh responden merespon positif bahwa audiovisual yang berfungsi dengan baik. visual yang digunakan dalam rangka mendukung terlaksananya pelatihan dapat berfungsi dengan baik. Baterai microphone juga tersedia di laci meja kelas untuk mengakomodir apabila sewaktu-waktu baterai microphone habis sehingga tidak terdapat kendala yang berarti.

Ketersediaan handouts yang berisi Seluruh responden merespon positif bahwa materi materi pelatihan. pelatihan yang berbentuk hardcopy handouts telah tersedia di meja masing-masing peserta berikut dengan seperangkat alat tulis (stationery kit) pada hari pertama diadakan pelatihan.

Materi pelatihan yang diberikan $83 \%$ dari 30 peserta atau sebanyak 25 orang aplikatif untuk pekerjaan seharihari. merespon positif bahwa materi pelatihan yang diberikan dapat diaplikasikan untuk pekerjaan sehari-hari sesuai pekerjaan Asisten Pembiayaan dan sisanya sebanyak 5 orang merespon bahwa materi pelatihan belum cukup aplikatif untuk pekerjaan sebagai Asisten Pembiayaan.

Viewer, AC, MIC, kursi, meja, Seluruh responden merespon positif bahwa notes, dan pena tersedia dan peralatan penunjang terlaksananya pelatihan telah berfungsi dengan baik. tersedia dan berfungsi dengan baik.

Pelaksanaan pelatihan sesuai dengan jadwal yang telah Seluruh responden merespon positif bahwa ditentukan jauh hari sebelumnya. pelaksanaan pelatihan sesuai dengan jadwal yang diberikan dan dimulai serta diakhiri tepat waktu.

Pelatihan yang diberikan membantu Seluruh responden merespon positif bahwa para karyawan bekerja dengan caracara baru dan lebih baik. pelatihan yang diikuti memberikan informasi tentang problem solving dan strategi dalam menyelesaikan pekerjaan Asisten Pembiayaan.

Berdasarkan hasil wawancara (Tabel 4) terhadap 30 responden yang merupakan peserta pelatihan, mayoritas responden setuju bahwa pelatihan yang diselenggarakan oleh Unit Learning Center telah dilakukan dengan baik dan sesuai kebutuhan pelatihan serta tujuan perusahaan. 
Beberapa rencana pengembangan pegawai (SDM) untuk tahun 2019 telah disusun yaitu (1) pemetaan talent classification berdasarkan penilaian kinerja dan kompetensi pegawai, (2) penyusunan Individual Development Program untuk pengembangan kompetensi pegawai, (3) penyusunan career path management dan succession plan yang mengacu pada kompetensi dan job family matrix, (4) pelaksanaan Management Development Program sebagai program pengembangan pegawai yang akan menjadi successor pimpinan, (5) pelaksanaan Leadership Development Program yang dilakukan untuk meningkatkan leadership skill para pemimpin incumbent, serta (6) pembenahan program coaching dan mentoring.

Rencana pengembangan tersebut diharapkan mampu menjadikan pegawai PT Bank BNI Syariah (Persero) Tbk salah satu aset berharga perusahaan yang senantiasa berkembang dan meningkat kapabilitasnya sehingga tujuan perusahaan dapat tercapai dengan optimal.

\section{Identifikasi Variabel-variabel Pelatihan di PT Bank BNI Syariah (Persero) Tbk}

Penelitian ini mengacu pada teori Kirkpatrick \& Kirkpatrick yang mengemukakan bahwa terdapat empat level evaluasi pelatihan yaitu reaksi, belajar, perilaku, dan hasil. Berdasarkan keempat level tersebut, peneliti mengidentifikasi variabel-variabel pelatihan yang paling dominan mempengaruhi kinerja asisten pembiayaan di PT Bank BNI Syariah (Persero) Tbk. Dengan demikian, tiap level evaluasi pelatihan yang mewakili variabel yang diteliti memiliki data yang berbeda. Hasil analisis masing-masing memiliki pengaruh terhadap peningkatan kapabilitas pegawai dan kinerja masing-masing peserta pelatihan.

Dalam mengidentifikasi variabel Reaksi, terdapat 10 pertanyaan yang ditanyakan kepada 30 responden terkait pelatihan yang telah dilakukan. Masingmasing responden memiliki jawaban yang berbeda namun mayoritas merespon positif pelatihan yang telah diberikan perusahaan. Hal tersebut dapat diketahui dari 100\% respon positif yang diberikan responden pada 8 pertanyaan dari total pertanyaan 10 butir, sisanya terdapat 2 pertanyaan yang memiliki respon negative namun dapat dijadikan bahan evaluasi bagi Unit Learning Center dan instruktur pelatihan terkait pelaksanaan pelatihan.

Pada variabel Belajar, data tersedia dalam nilai pre-test dan post-test yang telah dikerjakan oleh peserta sebelum dan setelah mengikuti pelatihan. Hasil rata-rata peningkatan nilai hasil pre-test dan post-test tidak terlalu dominan terlihat pengaruhnya terhadap kinerja. Namun demikian, pada level belajar, terdapat indikasi peningkatan sebesar $20 \%$ pada peserta pelatihan sebelum mendapatkan materi pelatihan dikomparasikan dengan setelah mendapatkan materi pelatihan. Gambar 3 merangkum data nilai pre-test dan post-test dari tiga angkatan Asisten Pembiayaan yang telah mengikuti pelatihan Administrasi Pembiayaan.

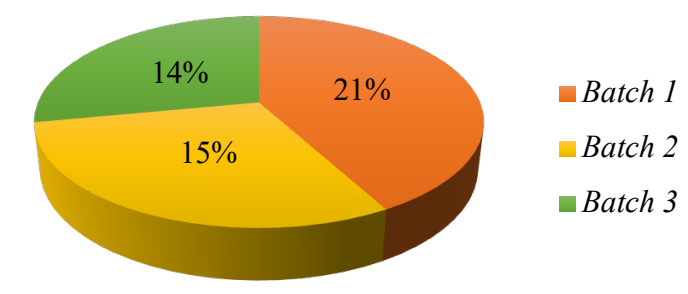

Gambar 3. Persentase Peningkatan Nilai Rata-rata per Angkatan pada Pelatihan Administrasi Pembiayaan Tahun 2018

Pelatihan Administrasi Pembiayaan Tahun 2018 diikuti oleh 167 peserta yang berasal dari Asisten Pembiayaan di seluruh cabang PT Bank BNI Syariah (Persero) Tbk di Indonesia. Angkatan 1 terdiri dari total peserta sebanyak 58 orang, Angkatan 2 sebanyak 59 orang, dan Angkatan 3 sebanyak 50 orang.

Selain variabel Reaksi dan Belajar, terdapat variabel Perilaku yang mengukur sejauh mana peserta dapat mengaplikasikan ilmu yang telah diberikan saat pelatihan dalam pekerjaan setelah mereka kembali 
bekerja. Proses evaluasi pelatihan pada level perilaku adalah dengan melakukan wawancara kepada 30 responden yang telah kembali ke cabang masing-masing dan beraktivitas sehari-hari dengan menerapkan pengetahuan serta strategi yang diperoleh dari pelatihan. Hasil wawancara menunjukkan bahwa $100 \%$ dari 30 responden menyatakan menggunakan caracara baru dan strategi baru dalam penyelesaian pekerjaan. Seluruh responden juga merasa lebih bersemangat dan termotivasi untuk bekerja lebih baik dan menghasilkan kinerja yang optimal. Dari 30 responden, seluruhnya berhasil meningkatkan target triwulanan sebesar 15$30 \%$ dari pencapaian target sebelumnya.

Pada variabel Hasil, penelitian ini menggunakan komparasi data target dan realisasi target yang diberikan kepada masing-masing Asisten Pembiayaan di awal tahun dengan aktivitas pemantauan pencapaian target melalui aktivitas harian. Aktivitas harian yang dimaksud adalah seperti morning briefing di unit terkait, progress report, weekly report, monthly report, pipeline report, dan annual report yang diketahui dan dilaporkan kepada Pemimpin Unit di masing-masing cabang. Dalam hal ini, wawancara dilakukan terhadap 30 responden yang menjadi sampel penelitian setelah mengikuti pelatihan. Hasil wawancara menyatakan bahwa dari 30 orang responden merasa percaya diri dan termotivasi untuk mencapai target yang telah diberikan perusahaan. Gambar 4 menyajikan data pertumbuhan pembiayaan mikro di PT Bank BNI Syariah (Persero) Tbk selama tiga tahun terakhir yang mendukung respon dari 30 responden penelitian.

Berdasarkan Gambar 4, dapat diketahui bahwa terjadi pertumbuhan pada penyaluran pembiayaan mikro dari tahuntahun sebelumnya. Peningkatan tahun 2018 sebesar 7,7\% yaitu dari Rp990 milyar menjadi Rp1.066 milyar. Hal tersebut selain mengindikasikan pertumbuhan aset, juga memperlihatkan bahwa program pelatihan yang diberikan kepada para asisten pembiayaan dan seluruh petugas di Unit Pembiayaan Mikro berdampak positif terhadap kinerja perusahaan. Variabel Perilaku merupakan variabel yang paling dominan dari pelatihan yang mempengaruhi peningkatan kinerja Asisten Pembiayaan di PT Bank BNI Syariah. Hal tersebut dinyatakan oleh seluruh responden sebanyak 30 orang yang menjadi peserta pelatihan Administrasi Pembiayaan. Para peserta mendapatkan pengalaman dan semangat serta motivasi untuk bekerja lebih cepat, teliti, efektif, dan efisien. Pernyataan responden tersebut didukung dengan pertumbuhan penyaluran pembiayaan mikro dari tahun sebelumnya sebesar 7,7\%. Pertumbuhan penyaluran pembiayaan mikro tersebut diiringi dengan konversi layanan cabang mikro menjadi general banking yang dapat memberikan layanan jasa perbankan segmen UMKM.

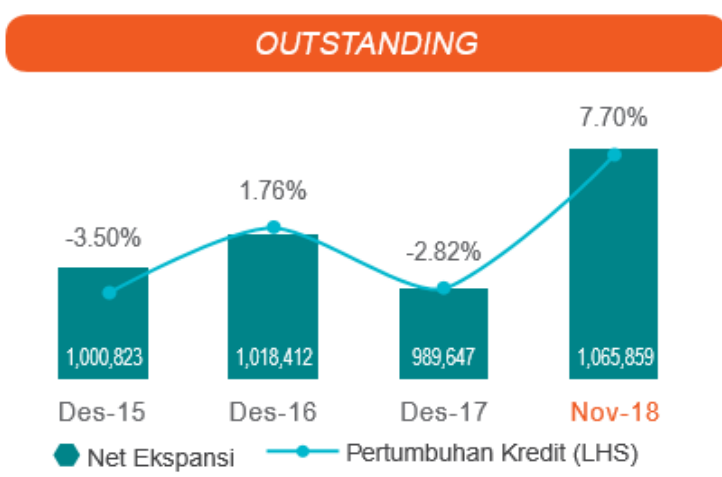

Gambar 4. Pertumbuhan Pembiayaan Mikro PT Bank BNI Syariah (Persero) Tbk

Sehubungan dengan fokus perusahaan dalam rangka pengembangan sumber daya insani, BNI Syariah melaksanakan program pengembangan pegawai berdasarkan spesifikasi dan tujuan penempatan pegawai pada tahun 2019. Program andalan seperti Officer Development Program dan Financing Officer Development Program tetap dilaksanakan di tahun-tahun mendatang. Tujuannya adalah untuk memenuhi kebutuhan pegawai yang fokus dan ahli dalam general banking dan pembiayaan produktif serta menjaring pemenuhan 
source pooling unsur pimpinan yang berlatar belakang pembiayaan produktif.

Pengelolaan talent di PT Bank BNI Syariah (Persero) Tbk terus dilakukan sejalan dengan tujuan perusahaan yaitu bertumbuhnya pembiayaan yang berkualitas seiring dengan meningkatnya DPK. Tantangan yang pasti dihadapi oleh segmen pembiayaan mikro adalah dinamika pada segmen micro banking nasional yang berimbas pada stagnasi pembiayaan di BNI Syariah. Pertimbangan pengelolaan talent harus tetap dilakukan, salah satunya juga dikarenakan hampir 30\% total pegawai BNI Syariah terdapat pada segmen micro banking sehingga Training Need Analysis dan pelatihan, baik inhouse training maupun public training, harus tetap dilaksanakan.

Pada variable Kinerja Karyawan, khususnya indikator Need for Supervision masih sangat dibutuhkan terkait proses pascapelatihan dalam hal evaluasi pelatihan. Supervisor di kantor cabang diharapkan mampu menilai kinerja karyawan yang baru saja menyelesaikan pelatihannya. Tidak hanya mampu menilai, namun juga mampu mengarahkan dan memonitor kinerja karyawan tersebut hingga karyawan yang merupakan peserta pelatihan tersebut mampu melanjutkan kinerja optimalnya dan menularkan kepada rekan kerja setingkat maupun rekan kerja di bawahnya sehingga peningkatan kinerja kantor cabang dapat ditunjukkan dengan baik. Seringkali, supervisor di kantor cabang juga menjadi mentor kerja ketika terdapat rekan kerjanya yang baru saja menyelesaikan pelatihan. Mentor kerja dalam hal ini adalah orang yang paling sering ditanyai ketika para karyawan mengalami kesulitan dalam mengimplementasikan ilmu yang diperoleh pascapelatihan.

\section{SIMPULAN DAN SARAN}

Berdasarkan hasil penelitian yang telah dilakukan, maka diperoleh kesimpulan pada Hipotesis 1 yang menyatakan bahwa terdapat pengaruh yang positif antara pelatihan terhadap kinerja Asisten Pembiayaan di PT Bank BNI Syariah, diterima. Hal tersebut ditunjukkan dari hasil evaluasi yang berupa checklist observasi terhadap lima hal yaitu peserta, instruktur, jangka waktu, materi pelatihan, dan bentuk pelatihan telah terpenuhi sesuai dengan harapan peserta dan penyelenggara. Kemudian, hasil evaluasi juga didukung dengan hasil wawancara melalui konfirmasi 10 pernyataan yang hasilnya menyatakan bahwa terdapat $100 \%$ respon positif pada 8 pernyataan dan sisanya sebesar $20 \%$ respon negative pada 2 pernyataan yang berbeda.

Hipotesis 2 yang menyatakan bahwa level perilaku merupakan variabel yang paling dominan dari pelatihan yang mempengaruhi kinerja Asisten Pembiayaan di PT Bank BNI Syariah, diterima. Hal tersebut diketahui dari hasil wawancara terhadap 30 responden yang seluruhnya mengalami perubahan khususnya dalam merumuskan strategi dan cara-cara baru menyelesaikan pekerjaan menjadi lebih efisien dan efektif. Selain itu pencapaian target triwulanan juga meningkat dibandingkan pada periode sebelumnya. Peningkatan target mencapai $15-30 \%$ bervariasi pada masing-masing peserta pelatihan.

Sehubungan dengan dua respon negatif pada dua pernyataan yang dikonfirmasi, akan lebih baik jika sebelum pelaksanaan pelatihan penyelenggara pelatihan dapat berdiskusi lebih intens dengan pemateri sehingga pemateri dapat menyiapkan materi yang aplikatif bagi para peserta pelatihan. Selain itu pemateri diharapkan menyiapkan banyak pembahasan kasus riil di industri perbankan dengan problem solving yang aplikatif dan baru.

Pada level perilaku yang berdampak paling dominan terhadap kinerja karyawan, akan lebih optimal apabila disertai dengan peran serta dan keterlibatan dari supervisor langsung sehingga seluruh aktivitas yang dilakukan oleh asisten pembiayaan sesuai dengan aturan perusahaan dan regulasi dari pihak eksternal yang berlaku serta petugas 
lebih termotivasi dalam memberikan kontribusi optimal terhadap perusahaan. Di masa depan, level hasil perlu ditingkatkan dengan melakukan evaluasi berkala (triwulan, semester, dan tahunan) pascapelatihan yang dilakukan oleh Unit Penyelenggara Pelatihan bekerja sama dengan supervisor di kantor cabang sesuai penempatan masing-masing karyawan.

\section{REFERENSI}

Alwi, S. (2008). Manajemen Sumber Daya Manusia: Strategi Keunggulan Kompetitif. Edisi Kedua. Yogyakarta: BPFE.

Bernardin, J. H. (2010). Human Resource Management: An Experiential Approach. Fifth Edition. Singapore: McGraw Hill.

Flippo, E. B. (2018). Manajemen Personalia. Edisi Keenam. Jakarta: Erlangga.

Dahmiri, D., \& Sakta, K. (2014). Pengaruh pelatihan terhadap kinerja pegawai dinas Pendidikan Kabupaten Sarolangun. Jurnal Manajemen Terapan dan Keuangan, 3(1), 374380.

Endayani, F. (2015). Pengaruh Pelatihan Kerja Terhadap Kemampuan Kerja dan Kinerja Karyawan (Studi Pada PT. BPRS Bumi Rinjani Kepanjen). Jurnal Administrasi Bisnis, 25(1).

Gibson, J. L., Ivancevich, J. M., \& Donelly, J. H. (1997). Organisasi (S. Soekrisno, Trans.). Jakarta: Erlangga.

Graha, A. N. (2005). Pengaruh Pelatihan Terhadap Kemampuan Karyawan dan Dampaknya Terhadap Kinerja Karyawan (Studi Pada Karyawan PT. Gatra Mapan Malang). Jurnal
Ekonomi Modernisasi, 1(2), 7593.

Hamalik, O. (2000). Pengembangan Sumber Daya Manusia, Manajemen Pelatihan Ketenagakerjaan Pendekatan Terpadu. Jakarta: Bumi Aksara.

Harahap, R. A. M., \& Silvianita, A. (2016). Pengaruh Pelatihan Terhadap Kinerja Karyawan PT Pos Indonesia (Persero) Regional $\mathrm{V}$ Bandung. eProceedings of Management, 3(2).

Indriantoro, N., \& Supomo, B. (1999). Metodologi Penelitian dan Bisnis. Yogyakarta: BPFE

Kirkpatrick, D. L., \& Kirkpatrick, J. D. (2006). Evaluating training programs: The four levels. San Francisco, CA: Berrett-Koehler.

Kirkpatrick, J. \& Kirkpatrick, W. K. (2009). The Kirkpatrick Four Levels: A Fresh Look After 50 Years 19592009. Kirkpatrick Partners.

Laporan Tahunan BNI Syariah. 2018. Leading Transformational Change. PT Bank BNI Syariah.

Simamora, H. (1998). Manajemen Sumber Daya Manusia. Edisi Kedua. Yogyakarta: Bagian Penerbitan STIE YKPN.

Simamora, H. (2004). Manajemen Sumber Daya Manusia. Edisi Ketiga. Yogyakarta: Bagian Penerbitan STIE YKPN

Sugiyono. (2006). Metode Penelitian Kuantitatif, Kualitatif dan $R \& D$. Bandung: Alfabeta.

Werther, W. B., \& Davis, K. (1996). Human resources and personnel management. New York: McGraw-Hill. 
